\title{
SUPPLY CHAIN INTEGRATION - A COMPETENCY BASED PERSPECTIVE
}

\author{
Krishnapriya $\mathrm{V}^{1}$ and Rupashree $\mathrm{Baral}^{2}$ \\ ${ }^{1}$ Department of Management Studies, IIT Madras, Chennai, India \\ ${ }^{2}$ Department of Management Studies, IIT Madras, Chennai,India
}

\begin{abstract}
The purpose of this paper is to signify the effect of inherent critical competencies on supply chain integration. A theoretical framework is proposed linking managerial, organizational and interorganizational competencies with supply chain integration and performance. Propositions are posited with suggestions for further research. Simultaneously, present paper looks at strategizing the different practices involved in successful management of a supply chain emphasizing on intra (internal consistency) and inter-organizational (external consistency) relations. The paper provides value to the academicians and practitioners in both the fields by focussing on the impact competencies have on supply chain management system. The results are expected to provide an integrated (intra and inter-organizational) perspective to academicians looking at studying competencies in the field of supply chain.
\end{abstract}

\section{KEYWORDS}

Competencies, inter-organizational competencies, supply chain integration, supply chain performance

\section{INTRODUCTION}

In the past decade, supply chain management as a research area has grown to receive major attention from academic communities across disciplines. Practitioners of different fields have also begun to realize it as a strategy which when used effectively creates value addition to the firm. Supply chain management (SCM) is the management of a network of interconnected businesses involved in the ultimate provision of product and service packages required by end customers (Harland, 1996). Within the requirements of the new competition, a shift in the level of intensity among trading partners emerges. Especially, in the current dynamic environment, firms look at expanding, merging, outsourcing or even redesigning the whole of their supply chain. Rapid changes in the purview of supply chain have brought in the development of networked supply chain wherein all firms integrate to increase the value of supply chain. Firms have successfully acknowledged integration as an essential facet to a dynamic supply chain. It therefore requires high levels of trust, commitment, and information sharing among supply chain partners. Therefore, it becomes imperative to develop a bundle of knowledge, skills and abilities among employees which are the key to developing and realizing organizational goals along with achieving inter firm integration.

Organizations involve in supply chain management in order to control product quality, inventory levels and expenses and at the same time focusing on long term performance of individual contributors or supply chain as a whole. However, the organizations have only recently recognized that performance of the people in the supply chain directs the success of the supply chain. A highly integrated supply chain demands an efficient workforce with the right organizational attributes to function at internal and external levels. Human resource practitioners at the same time have rarely tried to establish practices and processes that have implications on 
the organization's supply chain. It is also to be noted that there has been very little research into competencies in supply chain system. This could be attributed to the fact that literature linking operations and human resource field has begun to rise only recently.

Although, supply chain integration has been extensively researched in the past decade, the topic still continues to garner interest due to its multidimensional in nature. Only recently there has been a notable increase in studies focussing on the relationship between human resource activities or organizational aspects and supply chain success. While it has encouraged in integrating different fields together, antecedents with respect to people and organizational factors in achieving multidimensional integration still warrants empirical testing so that alternative perspectives is gained. Thus, it requires that the onus be shifted on to the people responsible as well as their roles, responsibilities and skill requirements. Along similar lines, competency management is one such function which can connect the likes of both the fields. Competences are described by Teece, Pisano and Shuen (1997) as interesting intangible assets that cannot be purchased from the market so they must be developed in-house. For instance, competences such as building trust, creating interdependencies and balancing power often facilitate integration and cooperation across companies within the supply chain (Ferrer, Storer, Santa \& Hyland, 2008). Barnes and Liao (2012) in their study emphasize the dearth in research emphasizing on competencies required of successful supply chain systems. As a result, examining competencies at individual and organizational level of a firm in a supply chain strengthens the ties between the two academically distinct fields of study (Krishnapriya \& Baral, 2013). Supply chain professionals become the drivers of the organizational change when it undergoes a shift from cooperation and coordination to collaboration, which requires high levels of trust and commitment. They are required to have larger awareness towards organization's objectives as well as collaborative skills to build up supply chain relationships.

Therefore, in this paper an attempt is made to explore the relationships among competencies at three levels (individual, organizational, inter-organizational), supply chain integration and its effect on overall supply chain performance.

\section{LITERATURE REVIEW} 2.1 Competencies

Competence as a concept has extended into varied fields of business dealing with human resource. Competencies are measurable and success in developing them forms a critical component of organizational capability. Although competencies have been studied at individual, team and organizational level, there is a dearth of empirical studies in the realm of supply chain management. At the individual level, competencies have been assessed mainly through case studies in supply chain management literature (Barnes \& Liao, 2012).

Boyatzis (1982) has noted that competencies are not determined by individual characteristics alone but characterised by job demands and organizational environment as well. While identifying five emerging trends in development of competencies and competency methods, Athey and Orth (1999) suggested growing emphasis on team and process competencies to enhance organizational performance. In order to achieve their strategic goals, organizations include core competencies that reflect their organizational goals and strategies developed to changing environments.

\subsection{Individual Competencies}

Lahti (1999) describe competency at the individual level, not as an independent collection of knowledge, skills, abilities and other characteristics (KSAO).A competency is at a higher, more 
general level which is an integration of KSAOs possessed by an individual and not just a cluster of behaviours. Additionally, a competency can be consistently verified by indirect indicators such as an individual's behaviours as well as through the individual's performance on tasks that are subject to evaluation.

The way a supply chain manager is perceived in the complex business environment has changed remarkably in the recent years. The role of supply chain professional has evolved from just being functional focused to process focused. Supply chain managers not only need to be equipped with the skills and knowledge to manage logistics but are also required to be relationship managers. Jayaram and Avittathur (2012) stated the limited availability of managerial talent with expertise in the key supply chain functions (procurement, logistics, demand planning, process management, etc.) in spite of abundant business schools and rising specialized programs in supply chain management. The expected demand and supply of good supply chain talent is projected to have a very obvious mismatch.

Although the membership in internationally recognized professional associations such as APICS, the Council of Supply Chain Management Professionals (CSCMP), and the Institute for Supply Management (ISM) is on rise, more widespread participation is required to advance the overall professional knowledge in this business discipline. As a result, academicians have tried to bridge the skill gap appearing at a global level. Lou (2012) reveals scarcest global skills and further breaks them down as soft and hard (job-specific) skills. Languages, people and communications, team management, leadership and organizational skills were ranked high on soft skills whereas budgetary, IT, green skills, procurement and negotiation, R\&D and healthcare rated high on hard skills. Along similar lines, Rahman and Yang (2009) identified the requirement of combination of hard and soft skills among logistic professionals in China. The analysis revealed that inventory management, supply chain awareness, cross-functional awareness, customer service, and supply chain cost are considered the top five skills for effective and efficient functioning.

Gammelgaard and Larson (2001) posited a three factor model of SCM skill areas for executive development aiming at logistics managers: interpersonal / managerial basic skills, quantitative/technological skills, and SCM core skills. With the focus being shifted to integrated supply chain, supply chain mangers need to be equipped with customer orientated skills, global perspective , cross functional understanding (Christopher, 2004) etc.. Thai, Cahoon and Tran (2011) studied the skills and knowledge of Australian logistics professionals. The study reported the five most important skills perceived by respondents as personal integrity, managing client relationships, problem-solving ability, cost control and ability to plan. Skills such as specialised software knowledge, strategic management, risk management, climate change and developing environmentally sustainable logistics systems were expected to become more important in the near future.

Based on similar comparative studies, Heyns and Luke (2012) composed and studied a list of 38 skills which were identified and considered as important skills required by logistics and supply chain managers (Gammelgaard \& Larson, 2001; Mangan \& Christopher, 2005; Mangan,Gregory \& Lalwani, 2001; Murphy \& Poist, 2006; Rahman \& Yang, 2009; Razzaque \& Bin Sirat, 2001; Thai, Cahoon \& Tran, 2011). Heyns and Luke (2012) in their study further grouped these 38 skills into 6 different categories, viz.:1) general management; 2) behavioural/interpersonal skills; 3) logistics awareness; 4) logistics analytical; 5) logistics information technology; and 6) environmental awareness. Therefore, these exhaustive list of competencies are adapted and used in studying the competencies among supply chain professionals in the current context and further, linking them with competencies at supply chain level in order to achieve supply chain integration. 
International Journal of Managing Value and Supply Chains (IJMVSC) Vol.5, No. 3, September 2014

\subsection{Organizational Competencies}

Organizational level competencies are an important source of competitive advantage. Along with allowing access to a vast number of business markets, competencies at this level substantially contribute to the customer's value of an end product, and become difficult for an organization's competitors to emulate (Lahti, 1999). A strategic architecture is developed within an organization to establish the objectives of competency building (Prahalad \& Hamel, 1990). Organizational level core competencies are the collection of knowledge, skills, abilities and other characteristics (KSAO) of an organization as a whole which in fact symbolizes organization's strengths.

Core competencies are the collective learning to coordinate diverse production skills and integrate multiple streams of technologies in an organization (Prahalad \& Hamel, 1990). They also represent the norms of the organizations that bind individuals into collectives. Organizational competencies disseminate to the entire organization of its competitive advantage which readily allocates resources to build individual competencies required for achieving successful supply chain performance. Thus, organizational competencies can be defined as an amalgam of required skills, necessary information, appropriate performance measures and the right corporate culture required by the company to achieve its mission. The constructs to represent organizational competencies have been identified as (i) Cross functional information sharing (ii) Intra-organizational knowledge sharing (iii) Participative culture (iv) Learning Orientation.

Cross-functional information sharing expects joint ownership of decisions and collective responsibility for outcomes of the supply chain. Kohli and Jaworski (1990) validated that firms focusing on market orientation aim to improve customer requirements based on information obtained from market and shared within the firm in coordination. Information gathered by individual firms can serve as the basis for shared information among supply chain partners, thus contributing to an integrated supply chain. Such norm can help in coordinating complex functional inputs of different entities resulting in high responsiveness to customers.

Participative culture encourages voluntary participation at all levels of an organization. It is also found to be effective in facilitating cross functional coordination (Eng, 2006). Participative culture influences coordination and integration of organization wide activities in SCM (Levy \& Grewal, 2000). Power, Sohal, and Rahman (2001) identified participative culture as an important attribute in achieving agile supply chain.

Intra-organizational knowledge sharing refers to expectations of the spread of learning among different units within an organization through knowledge sharing (Eng, 2006). Knowledge sharing across functions creates the opportunity for combining resources and applying knowledge. In particular, members of the supply chain must first view internal relationships as valuable resources in order to take advantage of external knowledge sharing between firms. The construct emphasizes the importance of the lessons learned from history and sharing them between departments.

Learning orientation refers to an organizational value that influences the tendency of an organization to create and use knowledge, and hence, to learn and adapt (Sinkula, Baker \& Noordewier, 1997). A learning oriented firm creates a culture conducive of sustained growth allowing new information and innovations to be created with data obtained from the market, as well as to establish a system to share it across the organization (Eris, Ozmen, \& Neczan, 2012). Sinkula et al. (1997) characterized learning orientation by (1) a commitment to learning, (2) open-mindedness and (3) shared vision. Commitment to learning refers to the relative value that a firm places on learning. Open mindedness relates to the concept of unlearning and to the emphasis that firms place on questioning the assumptions that govern. Shared vision relates to 
the direction of learning and provides a focus for organizational members with respect to energy, commitment and purpose. Generally, learning orientation has confirmed to have a positive impact on performance (Baker \& Sinkula, 1999). Also, organizational learning is considered as a strategic resource (Hult, Ketchen Jr. \& Nichols Jr., 2003) as well as affecting internal and external integration of the firm (Braunscheidel \& Suresh, 2009).

\subsection{Inter-Organizational Competencies}

The Inter-organizational competence as defined by Sanséau (2005) refers to the organization's capacity to identify, capture, use and optimize the resources in its environment to mange relationships with other partners in its environment and to simultaneously capitalize on resources and processes to survive and flourish. The organizations capacity to go beyond its boundaries and look at external consistency in order to manage and optimize inter-organizational resources forms a major component in inter-organizational competence.

Competencies have rarely been studied in the inter-organizational perspective. In order to gain inter-organizational competitive advantage, firms collaborate with other partners in supply chain by engaging in knowledge sharing routines (Dyer \& Singh, 1998), joint problem solving of operational and strategic issues. In a networked context, it is understood that focal organization's success depends on the relationship and network it establishes externally strengthening the need for development of inter-organizational competencies (Barnes \& Liao, 2012). The current study builds on contributions by Prajogo and Olhager (2011) along with constructs verified by Barnes and Liao (2012), Cao (2007) and Chen and Paulraj (2004) on supply chain collaborations. The Inter-organizational competency is enumerated by six constructs identified as (i) long term relationship orientation, (ii) information sharing, (iii) collaborative awareness, (iv) goal congruence, (v) incentive alignment, and (vi) decision synchronisation.

Firms in a supply chain have increasingly started to rely on strategic suppliers (Prahalad \& Hamel, 1990). This has led to long term relationship with suppliers (Ogden , 2006) and use fewer suppliers over a long term rather than keeping a large base of them in contracts. Recently, a report published by Food \& Agribusiness Research Advisory unit at Rabobank (2013) stated that when each member of the chain enters into longer-term partnerships, information relating to each link could be shared across parties, enabling greater flexibility (Leach, 2013). In contrast, the traditional model of short-term relationships that are independent of each other is insufficient to deal with changing supply dynamics. In relational marketing perspective, such an orientation has also proven to enable the exchange parties to cultivate relational norms that promote cooperation for mutual gains (Heide \& John, 1992; Macneil, 1980; Morgan \& Hunt, 1994).

Information sharing requires firms to exchange strategic supply chain information apart from transactional data, leading to improvement in the relationship and integration between the SC partners ((Hsu, Kannan, Tan \& Leong, 2008). The strategic supply chain information allows supply chain partners in making strategic decision in their operations ( $\mathrm{Li}$ et al., 2006).Information sharing becomes crucial in these turbulent economic times as it drives the firm into becoming a collaborative structure. Klein and Rai (2009) have also established that buyer and supplier strategic information flows positively impact the relationship-specific performance of both sharing and receiving parties. In addition, quality of information sharing refers to the extent to which a firm shares a variety of relevant, accurate, complete and confidential information in a timely manner with its supply chain partners (Monczka et al., 1998; Angeles \& Nath, 2003; Simatupang \& Sridharan, 2005; Sheu, Yen \& Chae, 2006).While information sharing is important, the impact of it on SCM depends on the quality with which it is shared (Holmberg, 2000). Given these predispositions, levels of information sharing as well as quality of information shared become critical aspects in deciding the supply chain success. 
Collaborative awareness as a construct has been defined by Barnes and Liao (2012) to study its relationship with organizational awareness and supply network competency. It looks at trusting, long-term relationship with the supplier, a term we refer to as collaborative awareness in this paper. Trust is an important element for inter-organizational system (IOS) enabled supply chain collaboration because trust can provide a foundation between collaborative partners for sharing critical information (Lejeune \& Yakova, 2005). Successful supply chain relationships should consist of partners that are willing to provide assistance to one another without exception; it is a relationship both parties are committed to and satisfied with. Barnes and Liao (2012) in their study defined collaborative awareness at the organizational level as the extent to which a firm perceives its trust and commitment with their supply chain partners. This relationship, therefore, exploits both the tacit and explicit knowledge of the networked firms resulting in creation of strategic Incentive alignment refers to the process of sharing costs, risks, and benefits among supply chain partners (Simatupang \& Sridharan,2005).Successful partnerships require participants to share gains and losses equitably, so that the collaboration outcomes are quantifiably beneficial to all (Manthou, Vlachopoulou \& Folinas, 2004).Supply chain members must align incentives which matches its investment in order for the collaboration to work. It helps in motivating the members to act in a manner consistent with overall objectives such as revealing confidential and relevant information (Simatupang \& Sridharan, 2005). It secures sufficient levels of cooperation and commitment (Harland, Zheng, Johnsen \& Lamming, 2004) and would allow the chain members to accept the importance of the potential rewards that can be achieved through collaboration even if the costs are to be shared (Simatupang \& Sridharan, 2005).The interaction of incentive alignment with other features of collaboration has also been acknowledged to be significant as it motivates the chain members to align their actions to the mutual purpose of collaboration that would also enhance their individual profitability (Simatupang \& Sridharan, 2002). Methods like expert systems, activity-based costing, and Webbased technology can be utilized to trace, calculate, and display incentive scores (Kaplan \& Narayanan, 2001).

Goal congruence between supply chain partners is the extent to which supply chain partners perceive their own objectives to be satisfied by the fulfilment of the supply chain objectives (Cao, 2007). In literature, congruence refers to alignment or fit. Therefore, when there is an alignment between the goals of the supply chain and that of the partners, it would lead to a higher level of partnership and successful collaboration (Eliashberg \& Michie, 1984). The needs and expectations of the partners have to be incorporated in the operations and strategies of a supply chain to enhance each chain member's profit, return- on- investment, and cash flow (Simatupang \& Sridharan, 2005). Collaboration requires mutual understanding and concurrence on certain beliefs, values and practices (Cao, 2007); goal congruence is one such key indicator to establish collaborative partnerships in a supply chain.

Decision synchronisation refers to the process where supply chain partners orchestrate decisions in supply chain planning and operations that optimise supply chain benefits (Simatupang \& Sridharan, 2005). In order to achieve a desirable set of objectives, firms engage in planning to determine a best way to utilize its resources. Mostly, decisions in supply chain involve planning and scheduling, procurement, and distribution management. Therefore, planning jointly helps in aligning partners and to coordinate decisions on inventory replenishment, order placement, and order delivery. At the same time, it is usually observed that supply chain partners have different decision rights and expertise. Therefore, very often supply chain partners have conflicting goals that guide decision making, which lead to solutions that are less than optimum (Lee, Padmanabhan \& Whang, 1997). Thus, supply chain partners should coordinate critical decisions that affect the way they increase performance. A way to judge decision synchronisation is the responsiveness of the supply chain partners in filling customer demands and the effectiveness of joint decisions in enhancing supply chain profitability (Corbett, Blackburn \& Van Wassenhove, 1999). Harland et al. (2004) in their study implied the level of synchronisation in the decision- 
making process as a key element of supply chain coordination and as a way of building and maintaining mutual partnerships.

Inter-organizational systems (IOS) refer to the information technology applications used in mediating buyer-supplier transactions and relationships (Subramani, 2004).Information technology acts as a facilitator in providing real time information sharing and permits the participants of a geographically dispersed supply chain to face lesser uncertainty and better interfirms coordination. Cash and Konsynski (1985) define IOS as automated information systems shared by two or more companies. Chi and Holsapple (2005) denote IOS as computer and communications infrastructure to manage interdependencies between firms. It is also an application system that links various partners in the supply chain using a public or private telecommunication infrastructure to provide computer-to-computer communication of business transactions and documents (Premkumar, 2000).Recent literature emphasizes use of IOS as an enabler of cooperation more than competition among independent firms (Hong, 2002; Kumar \& van Dissel, 1996).

\subsection{Supply Chain Integration and Performance}

Supply chain integration is the extent a manufacturer strategically collaborates with its supply chain partners and collaboratively manages intra- and inter-organizational processes (Flynn, Huo $\&$ Zhao, 2010). The definition of integration has gone through various modifications owing to research in different perspectives. An increase in level of SC integration will provide rapid access to required source of information, more sensitivity toward the needs of customers and enabling faster response time creating a competitive edge among competitors (Sezen, 2008). Lee (2000) suggested that well-integrated SCs create value for the shareholders by decreasing costs and increasing market share. Given the importance of supply chain integration, prior studies have examined a variety of topics to understand the composition of supply chain integration along with the factors that facilitate it, and the consequences of achieving it. Researchers that followed Frohlich and Westbrook's (2001) concept of arcs of integration have studied supply chain integration through different dimensions like strategic integration, relationship integration, internal integration, external integration and information integration. Specifically, the integration activities can be dealt either through forward mechanism which is from a supplier to a buying firm or through backward system going from a customer to a buying firm (Cousins \& Menguc, 2006). Kim (2013) recognized the role of participants in dealing with the flow and generating value arisen due to the direction of the integration being associated with the flow of material and information. Although some studies classify SCI into internal and external integration (e.g., Gimenez \& Ventura, 2005; Sanders, 2007), a number of studies have also looked at external integration in the perspective of both customer and supplier (Devaraj et al., 2007; Flynn et al., 2010; Zhao et al., 2011). Flynn et al., (2010) established the link between SC integration (customer, supplier and internal integration) and their interactions on performance. Gimenez, Vaart, and Donk (2012) in their research show that supply chain integration increases performance moderated by a context variable like supply chain complexity.

It becomes imperative to study performance aspect of a system whenever a procedure, a model, an approach, or any other research is undertaken (Beamon, 1999). Performance measurement is integral in evaluation of any system. It is very important as a strategic tool and also provides means to achieve the objectives required, fulfilling a firm's mission/strategy statement. In order for the supply chain to efficiently measure the overall performance, it has to distinguish itself from other performance measurement models by including suppliers, distributors etc. thereby making it multiple enterprises multiple measures type model. Various metrics have been considered to measure supply chain performance in the literature. Supply chain performance can be measured in varied dimensions like cost, quality, delivery, flexibility and reliability etc. (e.g., Schoenherr \& Swink, 2012) either in aggregation (e.g., Flynn et al., 2010) or in separation (e.g., 
Wong et al., 2011). Measurement systems like Balanced scorecard approach (Kaplan \& Norton, 1992), Supply-Chain Operations Reference-Model (SCOR) have gathered immense interest among academic-industry circles. Beamon (1999) presented a performance measurement system aiming at attaining goals of high efficiency, customer service and responsiveness to uncertain environment that would be adapted to the current context. Therefore, the performance measures utilized in this study ought to directly affect the real-world applicability.

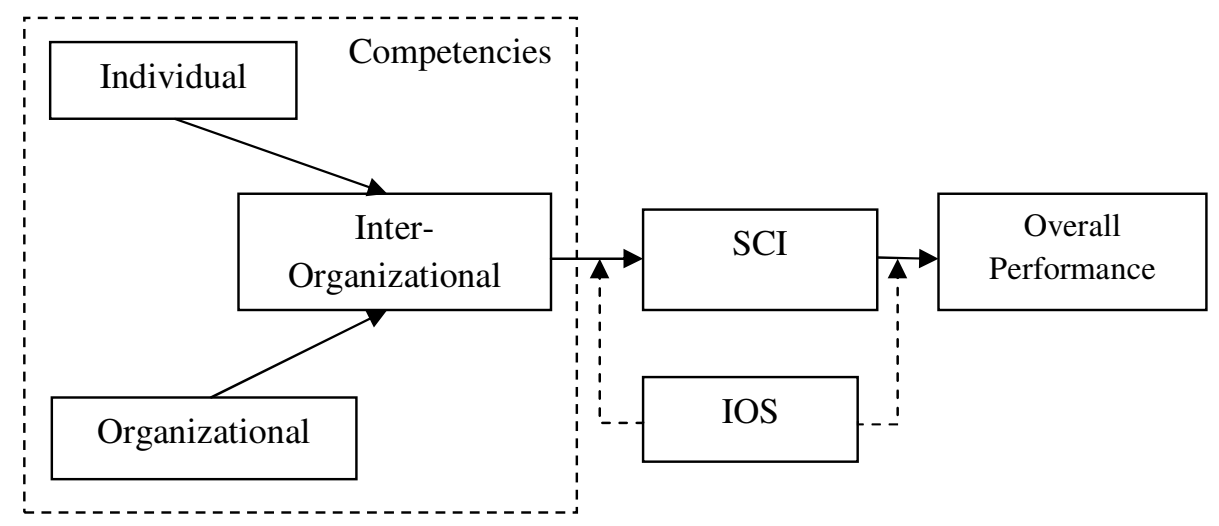

Figure 1- Theoretical Framework

\section{PROPOSED MODEL AND PROPOSITIONS}

Figure 1 elucidates the theoretical framework established out of extant literature and initial model presented by Barnes and Liao (2012) linking competencies and supply chain management system. We aim to posit the effect of competencies at individual, organizational and interorganizational level on supply chain integration that results in enhanced performance.

\section{a) Relationship between individual competencies and inter-organizational competencies}

Supply Chain Management (SCM) professionals work in an inter-organizational, multifunctional world. As supply chain leaders, they need to understand the big picture. They also need the ability to use a variety of tools and techniques to understand and manage the supply chain, as well as general skills to work with people and move their organizations forward. Operating within socially-rich network structures and utilizing varied non-hierarchical forms of collaborative activities which involves identifying problems and obtaining solutions turn out to be the attributes of a supply chain managers (Heide, 1994; Lambert, Emmelheintz \& Gardner, 1996). While performing various activities like building relationships with supply chain partners, sharing optimal information, synchronising decisions etc.; managers within supply networks collaboratively execute supply chain operations while maintaining their discretion and responsibility within their own organizations (Novicevic, Buckley\& Harvey, 2000).Possessing both technical and social competencies that are relational and contingent in nature have proved to be effective in sustaining network dynamics (Henderson \& Clockburn, 1995). Supply chain professionals when equipped with knowledge, skills, abilities and behaviour (put together as competencies) required for integrated supply chain are likely to influence the long term orientation of the focal firm, effective sharing of information among supply chain members and help in building collaborative relationship with SC partners.

Therefore, it is proposed that:

Proposition 1: Individual competencies are significantly related to the inter-organizational competencies of the focal firm. 


\section{b) Relationship between organizational competencies and inter-organizational competencies}

Individual firms in supply chain in order to gain competitive advantage develop certain norms and competencies which are consistent within the firm. These influence the way the firm performs in a supply chain thereby impacting the eternal consistency. In order to attain strategic advantage over other supply chains, firms require both the exploitation of existing internal and external firm-specific capabilities and developing new ones (Teece, 1982). In a way, competencies at a firm level impact internal integration of the firm. Consequently, organisations that are not internally integrated have fragmented and uncoordinated activities, and often spread throughout various organisational functions. Thus, as stated by Lambert and Stock (1993), internal integration means unifying functions and processes within the firm. Furthermore, Hyland, Davidson and Sloan (2003) indicated that for organisations contemplating innovation, managers need to consider their own competences and organisational capabilities, before contemplating radical or incremental innovation. Thus, for organisations to be able to establish inter firm relations, they need to deploy internal capabilities for internal integration. Thus, it is expected that:

Proposition 2: Organizational competencies are significantly related to the inter-organizational competencies of the focal firm.

\section{c) Relationship between inter-organizational competencies and supply chain integration}

Experts believe supply chain integration involves efficient management of information and closer organizational collaboration among supply chain partners. A closely integrated supply chain is effective only when it engages in information sharing activities and joint operational planning, which can be associated with firms' long term relationship orientation (Vanpoucke \& Vereecke, 2010). The movement of supply chain from coordination to collaboration or integration requires high levels of trust and commitment among partners. Morgan and Hunt (1994) suggest that trust and commitment, in this paper, collaborative awareness, are key foundations of inter-organizational partnerships because they are key drivers of joint plans and actions. Trust and commitment are key relational norms for building and sustaining partnerships among supply chain participants (Gounaris, 2005; Morgan \& Hunt, 1994). Close relationship is only possible with appropriately qualified suppliers. The integrated supply chain management concept needs to be subscribed by the qualified suppliers who will take time to let such partnerships take root and flourish. Consequently, a level of synchronization in the decisionmaking process may be seen as a key element of collaboration in supply chain and as a way of building and maintaining a set of mutual partnerships (Harland et al., 2004). The successful operation of supply chain partnerships mandates that each supply chain member should split gains and losses fairly and the collaboration outcome should be beneficial to all involved (Manthou et al., 2004).

Therefore, this study develops the following proposition:

Proposition 3: Inter-organizational competencies significantly impact the level of supply chain integration.

\section{d) Relationship between supply chain integration and overall performance}

Supply chain integration is expected to combine partners' resources and perspectives into a firm's value propositions, thereby allowing all companies in the network to excel in performance. Previous studies have highlighted the importance of supply chain integration by linking it with various outcomes like competitive advantage (e.g. Lee \& Billington, 1992), supply chain performance (Narasimhan \& Kim, 2002; Prajogo \& Olhager, 2012). Stank et al. (2001) implied the significance of internal and external collaboration for successful supply chain 
performance. Frohlich and Westbrook (2001) found evidence about the widest degree of arc of integration with both suppliers and customers having the strongest association with performance improvement. Sheu et al. (2006) found that higher levels of collaboration result in operational efficiency in the supply chain system in terms of inventory levels and levels of satisfaction. Li et al. (2009) found that supply chain integration is significantly related to supply chain performance with IT as an enabler. Van der Vaart and van Donk (2008) have tried to explore the practices involved in supply chain integration research and have stated that majority of empirical surveys on supply chain integration report a positive relationship between integration and performance.

Thus, we can formulate the following proposition:

Proposition 4: Supply chain integration has a significant impact on overall performance of the supply chain.

\section{e) Mediating role of inter-organizational competencies}

The role of inter-organizational competencies (e.g. information sharing, incentive alignment, collaborative awareness, etc.) as catalysts in developing strategic partnerships along with integrating a supply chain has been reflected by considerable empirical studies in recent studies (Barnes \& Liao, 2012; Pandey, Bhattacharyya \& Kaur, 2012; Simatupang \& Sridharan, 2005).Logistics and supply chain competencies of a manager contributes to a collaborative supply chain depending upon the competencies held by the firm in the supply chain network. In other words, stronger the composite competencies imbibed by the firm in the network, the more significant supply chain professionals' contribution to a firm's engagement in continuous improvement programs in that relationship. Along similar lines, competency at organizational level involve assessing an organization as a whole which is more challenging than assessing an individual due to the number of uncontrollable variables that can impact an organization's performance. Supply chain integration encompasses both internal and external integration; organizational competencies driving integration internally and inter-organizational competencies driving external integration. Thereby, the following proposition:

Proposition 5a: The relationship between individual competencies and supply chain integration is mediated by the inter-organizational competencies of the focal firm.

Proposition 5b: The relationship between organizational competencies and supply chain integration is mediated by the inter-organizational competencies of the focal firm.

\section{f) Moderating role of Inter-organizational systems (IOS)}

In the current dynamic economic conditions, firms have begun to implement and effectively use information technology to strengthen their supply chain partnerships and to attain greater collaborations. Using IOS, supply chain partners can develop close relationships in the chain structure, which enables them to access each other's privileged data and information (Holland, 1995). Previous studies have reported positive effects of information technology on dependent variables such as partner relationship, collaboration, supply chain performance, etc. (Bakos \& Brynjyoolfsson, 1993; Stump \& Sriram, 1997;Subramani, 2004). Even with these studies focusing on different types of technologies, positive effects of information technology on supply chain/inter-organizational collaboration were established in most studies. IOS enable the firm to remain integrated to multiple firms and facilitate in communicating vital information thereby enabling greater cooperation in addition to reducing uncertainty to a large extent. SC literature has mostly established direct link between IT and supply chain integration and performance. For example, while trying to establish a long term relationship, decision synchronization and sharing information, IOS rather than directly impacting on SC integration, could act as a support/facilitator in achieving higher levels of integration. Studies have also validated moderating effect of information technology on supply chain integration and performance (Chen \& Paulraj, 2007; Pandey et al., 2012). Investment in these systems will automatically bring 
supply chain integration, better collaboration with partners, and ultimately higher overall performance. Thus,

Proposition 6a:Inter-organizational systems moderate the relationship between interorganizational competencies and supply chain integration.

Proposition 6b:Inter-organizational systems moderate the relationship between supply chain integration and overall performance.

\section{CONCLUSION AND IMPLICATIONS}

The integration among the supply chain partners can be complex and requires unique capabilities that may be difficult or costly to imitate (Barney, 2012; Chen et al., 2009a, b). By managing these integrative relationships better than the firm's competitors, it transforms itself to be a valuable internal strategic resource. This can be achieved by developing certain competencies internal as well as external to achieve a sustainable competitive advantage. In this purview, the competency based approach is one such perspective that relies on the foundation of defining critical behaviours needed for effective individual, organizational performance and further extending it to inter-firm performance. By leveraging the capabilities required for higher integration, each member in the supply chain can achieve superior performance. Collaborating Operations Management with HRM can help Supply Chain partners in developing resilient inter firm relationships and creating knowledge sharing routines. Furthermore, it is becoming imperative to strategically build competencies internally as well as externally to ensure sustainable performance at all levels. Therefore, this paper reinforces the importance of aligning the competencies with the business strategies and objectives in order to sustain a highly integrated supply chain. This paper's significant contribution remains the need to merge the human resource management and supply chain management to achieve enduring results in both fields. Also, the extension of competency literature to include much important inter organizational competencies. More specifically, this study can help answer questions such as what type of competencies at each level (individual, organizational and inter-organizational) have the better probability to bring out higher benefits in terms of supply chain integration. The study results will help in justifying the need to align the supply chain workforce to bring in long term improvements in productivity and efficiency. It is also expected to present another perspective to strategic HRM wherein HR develops competencies among individuals by building organizational and process competencies. Certainly, the paper is clearly built on only theoretical foundations. Much empirical evaluations of specific competencies affecting supply chain integration can be taken up to validate the illustrated propositions.

\section{REFERENCES}

[1] Athey, T. R., \& Orth, M. S., (1999) "Emerging competency methods for the future", Human Resource Management, V o1.38, No. 3, pp. 215-225.

[2] Bakos, J. Y., \& Brynjyoolfsson, E., (1993) "From vendors to partners: Information technology and incomplete contracts in buyer-supplier relationships", Journal of organizational computing, Vol. 3, No. 3, pp. 301-329.

[3] Baker, W. E., \& Sinkula, J. M., (1999) "The synergistic effect of market orientation and learning orientation on organizational performance", Journal of the academy of marketing science, 27(4): 411-427.

[4] Barnes, J., \& Liao, Y., (2012) "The Effect of Individual, Network, and Collaborative Competencies on the Supply Chain Management System", International Journal of Production Economics. Vol. 140, No. 2, pp. 888-899.

[5] Barney, J. B., (2012) "Purchasing, supply chain management and sustained competitive advantage: The relevance of resource-based theory" , Journal of Supply Chain Management, Vol. 48, No. 2, pp. 3-6.

[6] Beamon, B. M., (1999) "Measuring supply chain performance", International Journal of Operations \& Production Management, Vol. 19, No. 3, pp. 275-292. 
[7] Braunscheidel, M. J., \& Suresh, N. C., (2009) “The organizational antecedents of a firm's supply chain agility for risk mitigation and response", Journal of Operations Management, Vol. 27, No. 2, pp. 119-140.

[8] Boyatzis, R. E., \& Royatzis, R., (1982) The competent manager: A model for effective performance. New York: Wiley.

[9] Burton, T.T., ( 1988) “JIT/repetitive sourcing strategies: tying the knot with your suppliers", Production and Inventory Management Journal, Vol. 29, No. 4, pp. 38-41.

[10] Calantone, R. J., Cavusgil, S. T., \& Zhao, Y., (2002) "Learning orientation, firm innovation capability, and firm performance", Industrial marketing management, Vol. 31, No. 6, pp. 515524.

[11] Cao, M., (2007) Achieving collaborative advantage through IOS-enabled supply chain collaboration: An empirical examination (Doctoral dissertation, The University of Toledo). Retrieved from ProQuest Dissertations \& Theses.

[12] Cash, J. I., \& Konsynski, B. R., (1985) "IS redraws competitive boundaries", Harvard Business Review, Vol. 63, No. 2, pp. 134-142.

[13] Chen, H., Daugherty, P. J., \& Landry, T. D., (2009a) "Supply chain process integration: A theoretical framework", Journal of Business Logistics, Vol. 30, No. 2, pp. 27-46.

[14] Chen, H., Daugherty, P. J., \& Roath, A. S., (2009b) "Defining and operationalizing supply chain process integration”, Journal of Business Logistics, Vol. 30, No. 1, pp. 63-84.

[15] Chen, I. J., \& Paulraj, A., (2004) "Towards a theory of supply chain management: the constructs and measurements", Journal of operations management, Vol. 22, No. 2, pp. 119150.

[16] Chi, L., \& Holsapple, C. W., (2005) "Understanding computer-mediated interorganizational collaboration: A model and framework", Journal of Knowledge Management, V o 1.9, No. 1, pp. 53-75.

[17] Christopher, M., (2004) Creating and sharing knowledge in logistics: developing the logistics manager of the future. Paper presented at the Educators Forum, European Logistics Association Eurolog 2004 conference, Budapest.

[18] Corbett, C. J., Blackburn, J. D., \& Van Wassenhove, L. N., (1999) "Partnerships to improve supply chains”, Sloan Management Review, Vol.40, No. 4, pp. 71-82.

[19] Cousins, P. D., Menguc, B., (2006) "The implications of socialization and integration in supply chain management”, Journal of Operations Management, Vol. 24, No. 5, pp. 604-620.

[20] Devaraj, S., Krajewski, L., \& Wei, J.C., (2007) "Impact of eBusiness technologies on operational performance: the role of production information integration in the supply chain", Journal of Operations Management, Vol. 25, No. 6, pp. 1199-1216.

[21] Ding, M. J., Kam, B. H., \& Lalwani, C. S., (2012) "Operational routines and supply chain competencies of $\mathrm{Chinese}$ logistics service providers", International Journal of ogistics Management, The, Vol. 23, No. 3, pp. 383-407.

[22] Dyer, J. H., \& Singh, H., (1998) "The relational view: Cooperative strategy and sources of interorganizational competitive advantage", Academy of management review, Vol. 23, No. 4, pp. 660-679.

[23] Eliashberg, J., \& Michie, D. A., (1984) "Multiple business goals sets as determinants of marketing channel conflict: An empirical study", Journal of Marketing Research, pp. 75-88.

[24] Eng, T. Y., (2006) "An investigation into the mediating role of cross-functional coordination on the linkage between organizational norms and SCM performance", Industrial Marketing Management, V ol. 35, No. 6, pp. 762-773.

[25] Deniz Eris, E., Ozmen, T., \& Neczan, O., (2012) "The effect of market orientation, learning orientation and innovativeness on firm performance: A research from Turkish logistics sector", International Journal of Economic Sciences and Applied Research, Vol. 5, No. 1, pp. 77-108.

[26] Ferrer, M., Storer, M., Santa, R., \& Hyland, P., (2008) Developing capabilities for innovation in supply chain relationships. Paper presented to 9th CINet Continuous Innovation Network conference, Universidad Politecnica de Valencia, Valencia, Spain.

[27] Flynn, B. B., Huo, B., \& Zhao, X., (2010) "The impact of supply chain integration on performance: A contingency and configuration approach" Journal of Operations Management, Vol. 28, No. 1, pp. 58-71.

[28] Frohlich, M. T., \& Westbrook, R., (2001) "Arcs of integration: an international study of supply chain strategies”, Journal of operations management, V o1. 19, No. 2, pp. 185-200. 
[29] Gammelgaard, B., \& Larson, P. D., (2001) "Logistics skills and competencies for supply chain management", Journal of Business Logistics, V o1. 22, No. 2, pp. 27-50.

[30] Gimenez, C., \& Ventura, E., (2005) "Logistics-production, logistics marketing and external integration: their impact on performance", International Journal of Operations \& Production Management, Vol. 25, No. 1, pp. 20-38.

[31] Gimenez, C., van der Vaart, T., \& van Donk, D. P., (2012) "Supply chain integration and performance: the moderating effect of supply complexity", International Journal of Operations \& Production Management, V ol. 32, No. 5, pp. 583-610.

[32] Gounaris, S. P., (2005) “Trust and commitment influences on customer retention: insights from business-to-business services”, Journal of Business Research, Vol. 58, No. 2, pp. 126140.

[33] Harland, C.M., (1996) "Supply chain management relationships, chains and networks", British Journal of Management, March 7, pp. 63-80.

[34] Harland, C. M., Zheng, J., Johnsen, T. E., \& Lamming, R. C., (2004) "A conceptual model for researching the creation and operation of supply networks", British Journal of Management, Vol. 15, No. 1, pp. 1-21.

[35] Heide, J., (1994) "Interorganizational governance in marketing channels", Journal of Marketing, Vol.58, pp. 71-85.

[36] Heide, J. B., \& John, G., (1992) “Do norms matter in marketing relationships?”, The Journal of Marketing, pp. 32-44.

[37] Henderson, R., \& Cockburn, I., (1994) "Measuring competence? Exploring firm effects in pharmaceutical research", Strategic management journal, Vol. 15, No. S1, pp. 63-84.

[38] Heyns, G., \& Luke, R., ( 2012) "Skills requirements in the supply chain industry in South Africa", Journal of Transport and Supply Chain Management, V o1. 6, No. 1, pp. 107125.

[39] Holland, C. P., (1995) "Cooperative supply chain management: The impact of interorganizational information systems", Journal of Strategic Information Systems, Vol. 4, No. 2, pp. 117-133.

[40] Holmberg, S., (2000) "A systems perspective on supply chain measurements", International Journal of Physical Distribution \& Logistics Management, Vol. 30, No. 10, pp. 847-868.

[41] Hong, I. B., (2002) "A new framework for interorganizational systems based on the linkage of participants' roles”, Information \& Management, V o1.39, No. 4, pp. 261-270.

[42] Hult, G. T. M., \& Ferrell, O. C., (1997) "A global learning organization structure and market information processing”, Journal of business research, Vol. 40, No. 2, pp. 155-166.

[43] Hult, G. T. M., Ketchen Jr, D. J., \& Nichols Jr, E. L., (2003) "Organizational learning as a strategic resource in supply management”, Journal of Operations Management, Vol. 21, No. 5, pp. 541-556.

[44] Hsu, C. C., Kannan, V. R., Tan, K. C., \& Leong, G. K., (2008) "Information sharing, buyersupplier relationships and firm performance: a multi-region analysis", International Journal of Physical Distribution \& Logistics Management, Vol. 38, No. 4, pp. 296-310.

[45] Hyland, P., Davison, G., \& Sloan, T., (2003) "Linking team competences to organisational capacity”, Team Performance Management, Vol. 9, No. 5/6, pp. 97-106.

[46] Jayaram, J., \& Avittathur, B., (2012) "Insights into India", Supply Chain Management Review, Vol. 16, No. 4, pp. 34-41.

[47] Kaplan, R., \& Narayanan, V. G., (2001) “Measuring and managing customer profitability”, Journal of Cost Management, V ol. 15, No. 5, pp. 5-15.

[48] Kaplan, R. S., \& Norton, P. D., (1992) "The Balance Scorecard measures that drives performance", Harvard Business Review, Jan-Feb, pp. 71-79.

[49] Kim, D. Y., (2013) "Relationship between supply chain integration and performance", Operations Management Research, Vol. 6, No. 1-2, pp. 74-90.

[50] Klein, R., \& Rai, A., (2009) "Interfirm strategic information flows in logistics supply chain relationships", MIS Quarterly, Vol. 33, No. 4, pp. 735-762.

[51] Kohli, A. K., \& Jaworski, B. J., (1990) "Market orientation: the construct, research propositions, and managerial implications", The Journal of Marketing, pp.1-18.

[52] Krishnapriya, V., \& Baral, R., (2013) Emerging role of people and organizational factors in supply chain management. In D.Chatterjee, M.Dhal \& S.P.Pati (Eds.), High-Tech People, High-Touch Hr: Are We Missing The Humane Touch? : 391-405. New Delhi: Bloomsbury Publications India Pvt. Ltd. 
[53] Kumar, K., \& Van Dissel, H. G., ( 1996) "Sustainable collaboration: Managing conflict and cooperation in interorganizational system", MIS Quarterly, Vol. 20, No. 3, pp. 279-300.

[54] Lahti, R. K., (1999) "Identifying and integrating individual level and organizational level core competencies", Journal of Business and Psychology, Vol. 14, No. 1, pp. 59-75.

[55] Lambert, D., Emmelheintz, \& Gardner D., (1996) "Developing and implementing supply chain partnerships" International Journal of Logistics Management, 18(1): 67-78.

[56] Lambert, D., \& Stock, J.R., (1993) Strategic logistics management, 3 rd edn. Irwin, CA: Homewood.

[57] Leach, A., (2013) Food supply chains need long-term relationships. , media release, 16 March, Supply management, http://www.supplymanagement.com/news/2013/food-supply-chainsneed-long- term-relationships/ viewed 20 March 2013.

[58] Lee, H. L., (2000) "Creating value through supply chain integration", Supply chain management review, Vol. 4, No. 4, pp. 30-36.

[59] Lee, H. L., \& Billington, C., (1992) "Managing supply chain inventory: pitfalls and opportunities", Sloan management review, Vol. 33, No. 3.

[60] Lee, H. L., Padmanabhan, V., \& Whang, S., (1997) "The bullwhip effect in supply chain", Sloan Management Review, Vol. 38, No. 3, pp. 93-102.

[61] Lejeune, M. A., \& Yakova, N., (2005) "On characterizing the 4 C's in supply chain management. Journal of Operations Management, V o1. 23, No. 1, pp. 81-100.

[62] Levy, M., \& Grewal, D., (2000) "Supply chain management in a networked economy", Journal of Retailing, Vol. 76, No. 4, pp. 415-429.

[63] Li, G., Yang, H., Sun, L., \& Sohal, A.S., (2009) "The impact of IT implementation on supply chain integration and performance", International Journal of Production Economics, Vol. 120, No. 1, pp. 125-138.

[64] Li, S., Ragu-Nathan, B., Ragu-Nathan, T. S., \& Subba Rao, S., (2006) "The impact of supply chain management practices on competitive advantage and organizational performance", Omega, Vol. 34, No. 2, pp.107-124.

[65] Lou, K., (2012) Top ten global skills shortages, media release, 14 March, Pharmiweb, http://www.pharmiweb.com/features/feature.asp?ROW_ID=1398 viewed 24 March 2013.

[66] Macneil, I. R., (1980) The New Social Contract: An Inquiry into Modern Contractual Relations. Yale University Press, New Haven, CT.

[67] Mangan, J., Gregory, O., \& Lalwani, C., (2001) "Education, training and the role of logistics managers in Ireland", International Journal of Logistics: Research and Applications, Vol. 4, No. 3. pp. 313-27.

[68] Mangan, J., \& Christopher, M., (2005) "Management development and the supply chain manager of the future", International Journal of Logistics Management, The, Vol. 16, No. 2, pp. 178-191.

[69] Manthou, V., Vlachopoulou, M., \& Folinas, D., ( 2004) "Virtual e-Chain (VeC) model for supply chain collaboration", International Journal of Production Economics, Vol. 87, No. 3, pp. 241-250.

[70] Marín-García, J. A., Alfalla-Luque, R., \& Medina-Lópe, C., (2012) Validation of supply chain integration scales and the effect that size, level of vertical integration, industry and country have on their value. $6^{\text {th }}$ International Conference on Industrial Engineering and Industrial Management Proceedings, July: 106-113.

[71] Martin, J. H., \& Grbac, B., (2003) "Using supply chain management to leverage a firm's market orientation”, Industrial marketing management, Vol. 32, No. 1, pp. 25-38.

[72] Morgan, R. M., \& Hunt, S. D., (1994) "The commitment-trust theory of relationship marketing", The journal of marketing, pp. 20-38.

[73] Murphy, P.R., \& Poist, R.F., (2006) "Skill Requirements of Contemporary Senior and Entry Level Logistics Managers: A Comparative Analysis”, Transport Journal, V o1. 45, No. 3, pp. 46-60.

[74] Narasimhan, R., \& Kim, S. W., (2002) "Effect of supply chain integration on the relationship between diversification and performance: evidence from Japanese and Korean firms", Journal of operations management, V o1. 20, No. 3, pp. 303-323.

[75] Novicevic, M. M., Buckley, M. R., \& Harvey, M. G., (2000) "The changing roles of managers within the supply chain networks: theory and practical implications", American Journal of Business, Vol. 15, No. 2, pp. 33-42. 
[76] Ogden, J. A., (2006) "Supply base reduction: an empirical study of critical success factors", Journal of Supply Chain Management, Vol. 42, No. 4, pp. 29-39.

[77] Pandey, P., Bhattacharyya, S., \& Kaur, A., (2012) "Exploring the role of HR practices in supply chain", Journal of Advances in Management Research, Vol. 9, No. 1, pp. 113-123.

[78] Paulraj, A., \& Chen, I. J., (2007) "Strategic buyer-supplier relationships, information technology and external logistics integration”, Journal of Supply Chain Management, Vol. 43, No. 2, pp. 2-14.

[79] Power, D. J., Sohal, A. S., \& Rahman, S. U, (2001) "Critical success factors in agile supply chain management-An empirical study", International Journal of Physical Distribution \& Logistics Management, Vol. 31, No. 4, pp. 247-265.

[80] Prahalad, C. K., \& Hamel, G., (1990) "The Core Competence of the Corporation", Harvard Business Review, 3, pp. 75-91.

[81] Prajogo, D., \& Olhager, J., (2012) "Supply chain integration and performance: The effects of long-term relationships, information technology and sharing, and logistics integration", International Journal of Production Economics, V ol. 135, No. 1, pp. 514-522.

[82] Premkumar, G. P., (2000) "Inter-organizational systems and supply chain management: An information processing perspective", Information Systems Management, V o1. 17, No. 3, pp. 57-69.

[83] Rahman, S. U., \& Yang, L., (2009) "Skills requirements for logistics managers in China", IIMB Management Review, Vol. 21, No. 2, pp. 140-148.

[84] Razzaque, M. A., \& Sirat, M. S. B., (2001) "Skill requirements: perception of the senior Asian logisticians", International Journal of Physical Distribution \& Logistics Management, Vol. 31, No. 5, pp. 374-395.

[85] Sanders, N. R., (2007) "An empirical study of the impact of e-business technologies on organizational collaboration and performance" Journal of Operations Management, Vol. 25, No. 6, pp. 1332-1347.

[86] Sanséau, P. Y., (2012) Competencies for the "Technological Europe" of Tomorrow: A New Model and an Emerging Concept of Interorganizational Competence. In D.G. Assimakopoulos, R. Dossani \& E.G. Carayannis (Eds.), Knowledge Perspectives of New Product Development: 123-140. Springer New York.

[87] Schoenherr, T., \& Swink, M., (2012) "Revisiting the Arcs of Integration: Cross-Validations and Extensions", Journal of Operations Management, Vol. 30, No. 1-2, pp. 99-115.

[88] Sezen, B., (2008) "Relative effects of design, integration and information sharing on supply chain performance", Supply Chain Management: An International Journal, Vol. 13, No. 3, pp. 233-240.

[89] Sharma, V., Giri, S., \& Rai, S. S., (2013) "Supply Chain Management of Rice in India: A Rice Processing Company's Perspective", International Journal of Managing Value and Supply Chains, Vol. 4, No. 1, pp. 25-36.

[90] Sheu, C., Yen, H.R., \& Chae, B., ( 2006) "Determinants of supplier-retailer collaboration: evidence from an international study", International Journal of Operations and Production Management, Vol. 26, No. 1, pp. 24-49.

[91] Simatupang, T. M., \& Sridharan, R., (2002) "The collaborative supply chain", International Journal of Logistics Management, Vol. 13, No. 1, pp. 15-30.

[92] Simatupang, T. M., \& Sridharan, R., (2005) "An Integrative framework for supply chain collaboration", International Journal of Logistics Management, Vol. 16, No. 2, pp. 257-274.

[93] Sinkula, J. M., Baker, W. E., \& Noordewier, T., (1997) "A framework for market-based organizational learning: linking values, knowledge, and behaviour", Journal of the academy of Marketing Science, Vol. 25, No. 4, pp. 305-318.

[94] Stank, T.P., Keller, S., \& Daugherty, P., (2001) "Supply chain collaboration \& logistical service performance", Journal of Business Logistics, Vol. 22, No. 1, pp. 29-48.

[95] Stump, R. L., \& Sriram, V., (1997) "Employing information technology in purchasing: buyersupplier relationships and size of the supplier base", Industrial Marketing Management, Vol. 26, No. 2, pp. 127-136.

[96] Subramani, M.R., (2004) "How do suppliers benefit from information technology use in supply chain relationships?”, MIS Quarterly, Vol. 28, No. 1, pp. 45-73.

[97] Subramani, M. R., (2004) "How do suppliers benefit from IT use in supply chain relationships", MIS Quarterly, Vol. 28, No. 1, pp. 50-75.

[98] Teece, D. J., (1982) “Towards an Economic Theory of the Multiproduct Firm”, Journal of 
International Journal of Managing Value and Supply Chains (IJMVSC) Vol.5, No. 3, September 2014

Economic Behavior and Organization, Vol. 3, pp. 39-63.

[99] Teece, D. J., Pisano, G., \& Shuen, A., (1997) "Dynamic capabilities and strategic management”, Strategic management journal, Vol. 18, No. 7, pp. 509-533.

[100] Thai, V. V., Cahoon, S., \& Tran, H. T., (2011) "Skill requirements for logistics professionals: findings and implications", Asia Pacific Journal of Marketing and Logistics, Vol. 23, No. 4, pp. 553-574.

[101] Van der Vaart, T., \& van Donk, D.P., (2008) “A critical review of survey-based research in supply chain integration”, International Journal of Production Economics, V o1.111, pp. $42-55$.

[102] Vanpoucke, E., \& Vereecke, A., (2010) "The predictive value of behavioural characteristics on the success of strategic alliances", International Journal of Production Research, Vol. 48, No. 22, pp. 6715-6738.

[103] Wong, C.Y., Boon-itt, S., \& Wong, C.W.Y., (2011) “The Contingency Effects of Environmental Uncertainty on the Relationship between Supply Chain Integration and Operational Performance", Journal of Operations Management, Vol. 29, No. 6, pp. 604-15.

[104] Zhao, X., Huo, B., Selen, W., \& Yeung, J. H. Y., (2011) "The impact of internal integration and relationship commitment on external integration", Journal of Operations Management, Vol. 29, No. 1-2, pp. 17-32. 